\title{
MANAJEMEN PENINGKATAN MUTU PENDIDIKAN BERBASIS SEKOLAH
}

\author{
Hamzah \\ STAIN Datokarama, Jl. Diponegoro No. 23 Palu \\ e-mail: hamzah_palu63@yahoo.com
}

\begin{abstract}
Abstrak. Harapan masyarakat akan pendidikan yang bermutu sejalan dengan tuntutan dunia usaha untuk memperoleh tenaga kerja yang berkualitas. Dengan demikian penyelenggara pendidikan, harus mampu merespon dan mengakomodir harapan dan tuntutan tersebut dalam proses pengambilan keputusan untuk peningkatan mutu pendidikan. Ini memberi keyakinan bahwa dalam proses pengambilan keputusan untuk peningkatan mutu pendidikan, dapat dipergunakan berbagai teori, perspektif dan kerangka acuan (framework) berbasis sekolah. Asumsi ini memberi konsekwensi bahwa sekolah harus menjadi bagian utama dalam proses pembuatan keputusan dalam peningkatan mutu pendidikan. Sementara masyarakat dituntut partisipasinya agar lebih memahami pendidikan, sedangkan pemerintah berperan dalam hal menentukan kerangka dasar kebijakan pendidikan.
\end{abstract}

Abstract. Popular expectations of quality education in line with the demands of the business world to obtain quality workers. Thus education providers, must be able to respond to and accommodate the expectations and demands of the decisionmaking process to improve the quality of education. This gives confidence that the decision-making process can be used a variety of theories, perspectives and frames of reference (framework)-based school. This assumption gives the consequence that a school should be a major part in the decisionmaking process in improving the quality of education. While public participation is required in order to better understand education, while government has a role in determining the basic framework of education policy.

Kata Kunci: Manajemen, Mutu Pendidikan, Berbasis Sekolah 


\section{PENDAHULUAN}

Ide menempatkan sekolah menjadi bagian utama dalam proses pembuatan keputusan dalam peningkatan mutu pendidikan, berbeda dengan konsep mengenai pengelolaan sekolah yang selama ini dipahami oleh masyarakat luas. ${ }^{1}$ Selama ini pengelolaan sekolah, lebih bayak diintervensi birokrasi pusat dan mendominasi proses pengambilan atau pembuatan keputusan pendidikan, yang bukan hanya kebijakan bersifat makro saja tetapi juga kepada hal-hal yang bersifat mikro.

Selama ini, sekolah cenderung hanya melaksanakan kebijakan-kebijakan birokrasi pusat yang belum tentu sesuai dengan kebutuhan belajar siswa, lingkungan sekolah, harapan orang tua dan masyarakat serta dunia usaha. Pengalaman menunjukkan bahwa sistem lama seringkali menimbulkan kontradiksi antara apa yang menjadi kebutuhan sekolah dengan kebijakan yang harus dilaksanakan dalam proses peningkatan mutu pendidikan.

Fenomena pemberian kemandirian kepada sekolah akan memperlihatkan suatu perubahan cara berpikir yang bersifat rasional, normatif dan menggunakan pendekatan perskriptif dalam pengambilan keputusan pandidikan. ${ }^{2}$ Hal ini tentu berimplikasi kepada suatu kesadaran akan kompleksnya pengambilan keputusan dalam sistem pendidikan dan organisasi yang mungkin tidak dapat diapresiasiakan secara utuh oleh kebijakan-kebijakan birokrat pusat.

Hal inilah yang kemudian mendorong munculnya pemikiran untuk beralih kepada konsep manajemen peningkatan mutu pendidikan berbasis sekolah sebagai pendekatan baru di Indonesia, yang merupakan bagian dari desentralisasi pendidikan yang tengah dikembangkan. Manajemen peningkatan mutu

${ }^{1}$ Depdiknas, Manajemen Peningkatan Mutu Berbasis Sekolah, (Jakarta: Direktorat Pendidikan Menengah Umum, 2000), h. 37.

${ }^{2}$ Ibid., h. 33. 
pendidikan berbasis sekolah (MPMBS) merupakan alternatif baru dalam pengelolaan pendidikan yang lebih menekankan kepada kemandirian dan kreatifitas sekolah.

Konsep ini mengacu pada teori effective school yang lebih memfokuskan diri pada perbaikan proses pendidikan. Beberapa indikator yang menunjukkan karakter dari konsep manajemen ini antara lain lingkungan sekolah yang aman dan tertib, sekolah memilki misi dan target mutu yang ingin dicapai, sekolah memiliki kepemimpinan yang kuat, adanya harapan yang tinggi dari personel sekolah (kepala sekolah, guru, dan siswa) untuk berprestasi.

Pengembangan konsep MPMBS didesain untuk meningkatkan kemampuan sekolah dalam mengelola perubahan pendidikan kaitannya dengan tujuan keseluruhan, kebijakan, strategi perencanaan, inisiatif kurikulum yang telah ditentukan oleh pemerintah dan otoritas pendidikan. Pendidikan ini menuntut adanya perubahan sikap dan tingkah laku seluruh komponen sekolah; kepala sekolah, guru dan staf administrasi termasuk orang tua dan masyarakat.

Seluruh komponen sekolah harus pro aktif dan terlibat langsung dalam melaksanakan monitoring dan evaluasi terhadap segenap kebijakan pengelolaan sekolah yang bersangkutan dengan didukung oleh pengelolaan sistem informasi yang representatif dan valid. Akhir dari semua itu ditujukan kepada keberhasilan sekolah untuk menyiapkan pendidikan yang berkualitas/bermutu bagi masyarakat dan dapat memenuhi harapan dunia kerja.

Dalam implementasi konsep MPMBS, sekolah memiliki tanggung jawab untuk mengelola dirinya berkaitan dengan permasalahan administrasi, keuangan dan fungsi setiap personil sekolah di dalam kerangka arah dan kebijakan yang telah dirumuskan oleh pemerintah. Bersama-sama dengan orang tua dan masyarakat (para aktor-aktor/stakeholders) yang terkait, 
sekolah harus membuat keputusan, mengatur skala prioritas di samping harus menyediakan lingkungan kerja yang lebih profesional.

Kepala sekolah harus tampil sebagai koordinator dari sejumlah orang yang mewakili berbagai kelompok yang berbeda dalam masyarakat untuk memberikan masukan dan saran-saran perbaikan. Sementara sekolah secara profesional harus terlibat dalam setiap proses perubahan melalui penerapan prinsip-prinsip pengelolaan kualitas total dengan menciptakan kompetisi dan penghargaan di dalam sekolah itu sendiri maupun sekolah lain.

Sistem kompetisi tersebut mendorong sekolah untuk terus meningkatkan diri, sedangkan penghargaan akan dapat memberikan motivasi dan meningkatkan kepercayaan diri setiap personil sekolah, khususnya siswa. ${ }^{3}$ Jadi sekolah harus mengontrol semua sember daya termasuk sumber daya manusia yang ada, dan lebih lanjut harus menggunakan secara lebih efisien sumber daya tersebut untuk hal-hal yang bermanfaat bagi peningkatan mutu pendidikan.

Dipilihnya konsep MPMBS sebagai model desentralisasi pendidikan untuk pendidikan dasar dan menengah karena diyakini model ini akan mempermudah pencapaian tujuan pendidikan. Ciri-ciri MPMBS adalah adanya otonomi yang kuat pada tingkat sekolah, peran aktif masyarakat dan menjunjung tinggi akuntabilitas dan trasnparansi dalam setiap keagiatan pendidikan. ${ }^{4}$

Program MPMBS bertujuan untuk memandirikan atau memberdayakan sekolah melalui pemberian kewenangan, keluwesan dan sumberdaya untuk meningkatkan mutu kinerja sekolah dan pendidikan terutama meningkatkan hasil belajar

${ }^{3}$ Salfen Hasri, Kepemimpinan Kepala Sekolah dari Kerangka Desentralisasi dan Otonomi Sekolah, (Edisi Khusus-HUT-FE-UM. Oktober, 2002), h. 19.

${ }^{4}$ Depdiknas, Manajemen Peningkatan..., h. 29. 
siswa Model MPMBS dapat dikatakan sebagai model manajemen yang memberikan otonomi yang lebih besar kepada sekolah, memberikan fleksibilitas keluwesan-keluwesan kepada sekolah dan mendorong partisipasi secara langsung warga sekolah sebagai aktor-aktor atau stakeholders yang sangat berperan dalam pelaksanaan kebijakan MPMBS di suatu sekolah.

Koalisi dan keterlibatan aktor-aktor/stakeholders yang terkait, sangat menentukan tercapai atau tidak tercapainya peningkatan mutu pendidikan di sekolah, khususnya dalam pelaksanaan (implementasi) kebijakan MPMBS. $^{5}$ Bahwa pendidikan dasar merupakan pendidikan umum (general education), artinya pendidikan dasar merupakan pendidikan minimum yang berlaku untuk semua negara, tanpa kecuali.

\section{PANDANGAN STAKEHOLDERS TERHADAP KEBIJAKAN MPMBS}

Penyelenggaraan pendidikan yang sangat sentralistik, menempatkan sekolah sebagai pendidikan sangat tergantung pada keputusan birokrasi yang mempunyai jalur sangat panjang dan kadang-kadang kebijakan yang dikeluarkan tidak sesuai kondisi sekolah setempat. Sekolah kehilangan kemandirian, motivasi dan inisiatif untuk mengembangkan dan memajukan lembaganya termasuk peningkatan mutu pendidikan sebagai salah satu tujuan pendidikan nasional.

Partisipasi masyarakat selama ini pada umumnya lebih banyak bersifat dukungan input, bukan pada proses pendidikan yakni pengambilan keputusan, monitoring, evaluasi dan akuntabilitas. Berkaitan dengan akuntabilitas, sekolah tidak mempunyai beban untuk mempertanggungjawabkan hasil pelaksanaan pendidikan kepada masyarakat, khususnya orang tua siswa, sebagai salah satu pihak utama yang berkepentingan dengan pendidikan (stakeholders).

${ }^{5}$ Salfen Hasri, Kepemimpinan..., h. 39. 
Berdasarkan kenyataan-kenyataan tersebut di atas, maka perlu dilakukan upaya-upaya perbaikan yaitu melakukan reorientasi penyelenggaraan pendidikan, dari manajemen peningkatan mutu berbasis pusat menuju manajemen peningkatan mutu berbasis sekolah. MPMBS dapat diartikan sebagai pengkoordinasian dan penyerasian sumberdaya yang dilakukan secara mandiri oleh sekolah dengan melibatkan semua kelompok kepentingan yang terkait (stakeholders).

Keterlibatan actor/stakeholders secara langsung dalam proses pengambilan keputusan untuk memenuhi kebutuhan mutu sekolah atau untuk mencapai tujuan mutu sekolah dalam kerangka kebijakan pendidikan nasional. ${ }^{6}$ Sekolah memiliki kewenangan (otonomi) atau kemandirian lebih besar dari sebelumnya untuk mengelola sekolahnya (menetapkan sasaran peningkatan mutu, menyusun rencana utama pengelolaan proses pendidikan, peningkatan mutu)

Sedangkan unit-unit di atasnya (Kandep, Kanwil, Depdiknas) merupakan pendukung-pelaksanaan peningkatan mutu pendidikan), khususnya dalam pengelolaan pengambilan keputusan partisipatif dan merupakan ciri peningkatan mutu khas MPMBS. Dipilihnya MPMBS sebagai model desentralisasi pendidikan untuk pendidikan dasar karena diyakini model ini akan mempermudah pencapaian tujuan pendidikan.

Ciri-ciri MPMBS adalah adanya otonomi yang kuat pada tingkat sekolah, peran serta aktif masyarakat dalam pendidikan, proses pengambilan keputusan yang demokratis dan berkeadilan, serta menjunjung tinggi akuntabilitas dan trasnparansi dalam setiap keagiatan pendidikan. ${ }^{7}$ Program MPMBS bertujuan untuk memandirikan, memberdayakan sekolah melalui pemberian

\footnotetext{
${ }^{6}$ Rumtini dan Jiyono, "Manajemen Berbasis Sekolah: Konsep dan Strategi Pelaksanaannya di Indonesia" dalam Jurnal Pendidikan dan Kebudayaan, Juni Tahun Ke 5 No. 017, (2008), h. 77.

${ }^{7}$ Nurkolis, "Manajemen Berbasis Sekolah: Hakekat Desentralisasi Model MBS" dalam Article Pendidikan Network (English), (Juni, 2001), h. 28.
} 
kewenangan, keluwesan dan sumberdaya untuk meningkatkan mutu kinerja sekolah.

Selain itu, konsep MPMBS diperkenalkan oleh teori "effective school" yang memfokuskan diri pada perbaikan proses pendidikan. Mengingat sekolah sebagai unit pelaksana pendidikan formal terdepan dengan berbagai keragaman potensi yang memerlukan layanan pendidikan, kondisi lingkungan yang berbeda satu dengan lainnya, maka sekolah harus dinamis dan kreatif dalam melaksanakan perannya untuk mengupayakan peningkatan mutu pendidikan.

Beberapa indikator yang menunjukkan karakter dari konsep manajemen ini antara lain sebagai berkut:

(1) lingkungan sekolah yang aman dan tertib; (2) sekolah memiliki misi dan target mutu yang ingin dicapai; (3) sekolah memiliki kepemimpinan yang kuat; (4) adanya harapan yang tinggi dari personil sekolah (kepala sekolah, guru dan staf lainnya termasuk siswa) untuk berprestasi; (5) adanya pengembangan staf sekolah yang terus menerus sesuai tuntutan IPTEK; (6) adanya pelaksanaan evaluasi yang terus menerus terhadap berbagai aspek akademik dan administratif; (7) adanya komunikasi dan dukungan intensif dari orang tua murid/masyarakat. ${ }^{8}$

Stakeholders melihat bahwa konsep MPMBS dapat dilaksanakan jika sekolah dengan berbagai keragamannya, diberikan kepercayaan untuk mengatur dan mengurus dirinya sendiri sesuai dengan kondisi lingkungan dan kebutuhan anak didiknya. Artinya perlu diberikan otonomi yang luas kepada sekolah melalui desentralisasi pendidikan di mana pada saat ini wacana desentralisasi pendidikan oleh pemerintah mulai ramai dikaji.

Dalam konsep MPMBS upaya peningkatan mutu pendidikan dilakukan melalui desentralisasi pendidikan kepada pemerintah kota/kabupaten. Melalui desentralisasi pendidikan diharapkan permasalahan pokok pendidikan yaitu masalah mutu,

${ }^{8}$ Umaedi Parakasi, Manajemen Peningkatan Mutu Berbasis Sekolah, (Cet. VIII; Malang: UMM Press, 2005), h.20. 
pemerataan, relevansi, efisiensi dan manajemen, dapat terpecahkan cukuplah desentralisasi pendidikan pada tingkat pemerintah kota/kabupaten.

Pengalaman berbagai negara menunjukkan bahwa desentralisasi pendidikan tidak cukup hanya pada tingkat kota/kabupaten. ${ }^{9}$ Desentralisasi pendidikan untuk mencapai otonomi pendidikan oleh para aktor/stakeholders sesungguhnya harus sampai pada tingkat sekolah secara individual. Sementara itu melalui kewenangan pemerintah daerah kabupaten/kota impelementasi konsep MPMBS, diharapkan mutu pendidikan dapat ditingkatkan.

Namun dalam pencapainnya tidaklah mudah, daerah akan mengalami masalah dan hambatan yang tidak sedikit, beberapa permasalahan pokok yang secara potensial menghambat pencapaian kualitas pendidikan terutama pendidikan dasar. Permasalahan-permasalahan menjadi kendala dalam meningkatkan mutu pendidikan pada era otonomi daerah.

Pendidikan dasar merupakan pendidikan umum (general education), artinya pendidikan dasar merupakan pendidikan minimum yang berlaku untuk semua negara, tanpa kecuali. Dalam pasal 11 ayat (2) UUSPN dikemukakan bahwa pendidikan umum merupakan pendidikan yang mengutamakan perluasan pengetahuan dan peningkatan keterampilan peserta didik dengan pengkhususan yang diwujudkan pada tingkat-tingkat akhir pendidikan.

Khusus mengenai sekolah dasar, hal ini mengingat peran pendidikan dasar sebagai bentuk satuan pendidikan dasar yang menyelenggarakan program sembilan tahun dan pada tahap inilah keberhasilan murid ditentukan, anak memperoleh dasardasar pendidikan yang penting untuk pendidikan selanjutnya, dan diharapkan tahap ini akan membantu mengarahkan

${ }^{9}$ Nurkholis, Manajemen Berbasis..., h. 33. 
pendidikan lebih lanjut termasuk keberhasilan pendidikan di tingkat pendidikan berikutnya.

Menurut pandangan para aktor/stakeholders bahwa implementasi konsep MPMBS kaitannya dengan peningkatan mutu pendidikan merupakan suatu proses yang terintegrasi dengan proses peningkatan kualitas sumber daya manusia itu sendiri. Pendidikan adalah esensial bahkan merupakan salah satu elemen terpenting dari kehidupan seseorang. Harus diakui bahwa tingkat pendidikan dapat menjadi ukuran tingkat kemampuan berfikir seseorang.

Para aktor/stakeholders melihat masalah pendidikan bukanlah hal mudah dan sederhana, karena selain sifatnya yang kompleks, dinamis dan kontekstual, pendidikan merupakan wahana untuk pembentukan diri seseorang secara keseluruhan. Peranan pendidikan dalam pembentukan diri dibahas secara rinci sebagai tujuan pendidikan yang meliputi aspek kognitif berupa keterampilan akademik dan keterampilan berfikir yang lebih tinggi.

Pendidikan dalam prosesnya juga mencakup tujuan pengembangan aspek pribadi dan sosial yang memungkinkan orang bekerja dan hidup dalam kelompok secara kreatif, inisiatif, empati dan yang memiliki keterampilan interpersonal yang memadai sebagai bekal bermasyarakat. Sedangkan tugas pendidikan adalah memberikan bekal kepada peserta didik agar potensinya berkembang, wajar, optimal dan bersifat adaptif dalam menghadapi berbagai permasalahan yang akan dihadapi pada masa-masa kehidupan berikutnya.

Melalui implementasi konsep MPMBS, sifat dasar manusia yang skeptis, eksploratif, dan juga kreatif, bisa berkembang dan menemukan artikulasinya dalam proses belajar mengajar sewaktu mengikuti suatu program pendidikan. Lulusan yang skeptis, inovatif, dedikatif, eksploratif, kreatif dan berkemampuan daya saing menjadi bahan antisipasi sistem dan perencanaan 
pendidikan terutama di era otonomi daerah di mana kondisi ekonomi akan tumbuh dengan cepat.

Dengan demikian, pandangan aktor/stakeholders tentang implementasi konsep MPMBS searah dan sejalan dengan tujuan pendidikan nasional yakni mengembangkan manusia Indonesia sesuai fitrahnya menjadi pribadi yang beriman dan bertaqwa terhadap Tuhan Yang Maha Esa, berakhlak mulia, menguasai ilmu rohani, memiliki keterampilan hidup yang berharkat dan bermartabat, memiliki kepribadian yang mantap dan mandiri serta memiliki tanggung jawab kemasyarakatan dan kebangsaan.

\section{KETERLIBATAN AKTOR/STAKEHOLDERS DALAM IMPLEMENTASI KEBIJAKAN MPMBS}

Bidang pendidikan memang menjadi tumpuan harapan bagi peningkatan kualitas Sumber Daya Manusia (SDM) Indonesia untuk menghadapi proses globalisasi di hampir semua aspek kehidupan. ${ }^{10}$ Kualitas SDM kita masih rendah, data UNDP tentang Human Development Index (HDI) menunjukkan dari 174 negara, Indonesia berada pada posisi yang sangat memprihatinkan hanya berada satu tingkat lebih baik dari Vietnam yaitu pada posisi 109.

Selain itu International Association of Education Evaluation in Achievement (IEA) menerbitkan hasil survei prestasi belajar matematika dan IPA bagi siswa sekolah usia 13 tahun pada 42 negara, berdasarkan hasil survei tersebut Indonesia berada pada posisi 39 untuk kemampuan IPA, dan urutan ke 40 untuk prestasi belajar matematika. Ini menunjukkan bahwa mutu pendidikan kita memang sangat rendah dan menghawatirkan.

Menyadari pentingnya proses peningkatan kualitas sumber daya manusia, maka pemerintah bersama kalangan swasta (aktor/stakeholders) sama-sama telah dan berupaya mewujudkan amanat tersebut melalui berbagai usaha pembangunan

${ }^{10}$ Salladien, Alternatif Model Pendidikan Berorientasi Dunia Kerja, (Edisi Khusus-HUT-FE-UM. Oktober, 2002), h. 10. 
pendidikan yang lebih berkualitas melalui pengembangan kurikulum dan sistem evaluasi, perbaikan sarana pendidikan, pengembangan dan pengadaan materi ajar, serta pelatihan bagi guru dan tenaga kependidikan lainnya yang dilakukan secara terencana dan kotinyu.

Tetapi pada kenyataannya upaya pemerintah tersebut belum cukup berarti dalam meningkatkan mutu pendidikan. Salah satu indikator kekurangberhasilan ini ditunjukkan antara lain dengan NEM siswa untuk berbagai bidang studi pada jenjang SLTP dan SLTA yang tidak memperlihatkan kenaikan yang berarti bahkan boleh dikatakan konstan dari tahun ke tahun, kecuali pada beberapa sekolah dengan jumah yang relatif sangat kecil.

Dalam kajian MPMBS, ada dua faktor yang dapat menjelaskan mengapa upaya perbaikan mutu pendidikan selama ini kurang berhasil. Pertama, strategi pembangunan pendidikan selama ini lebih bersifat input oriented. Strategi yang demikian lebih bersandar kepada asumsi bahwa bilamana semua input pendidikan telah dipenuhi, seperti penyediaan buku-buku (materi ajar) dan alat belajar lainnya, penyediaan sarana pendidikan, pelatihan guru dan tenaga kependidikan lainnya, maka secara otomatis lembaga pendidikan akan dapat menghasilkan output (keluaran) yang bermutu sebagai mana yang diharapkan.

Ternyata dalam implementasi kebijakan MPMBS, strategi input-output yang diperkenalkan teori education production function tidak berfungsi sepenuhnya di lembaga pendidikan (sekolah), melainkan hanya terjadi dalam institusi ekonomi dan industri. Kedua, pengelolaan pendidikan selama ini lebih bersifat macro-oriented, diatur oleh jajaran birokrasi di tingkat pusat. Akibatnya, banyak faktor yang diproyeksikan pada tingkat makro (pusat) tidak berjalan sebagaimana mestinya pada tingkat mikro (sekolah).

Keterlibatan aktor/stakeholders dalam implementasi kebijakan MPMBS menunjukkan bukti kuat ada permasalahan 
serius pada mutu pendidikan. Dapat dikatakan bahwa kompleksitas permasalahan pendidikan, seringkali tidak dapat terpikirkan secara utuh dan akurat oleh birokrasi pusat. Bahwa pembangunan pendidikan bukan hanya terfokus pada penyediaan faktor input pendidikan saja tetapi juga harus lebih memperhatikan faktor proses pendidikan.

Input pendidikan merupakan hal yang mutlak harus ada dalam batas-batas tertentu tetapi tidak menjadi jaminan dapat secara otomatis meningkatkan mutu pendidikan, school resources are necessary but not sufficient condition to improve student achievement. Dengan memperhatikan beberapa penjelasan implementasi yang telah dijelaskan di atas, maka kajian implementasi merupakan suatu proses mengubah gagasan atau program menjadi tindakan, dan bagaimana kemungkinan cara menjalankan perubahan tersebut.

Untuk menganalisis keterlibatan aktor/stakeholders dalam implementasi kebijakan MPMBS, maka dapat dilihat dari berbagai model-model implementasi kebijakan. Pandangan mengenai model (teori) implementasi kebijakan banyak kita temukan dalam berbagai literatur, misalnya Parsons, 1997 membagi garis besar model implementasi kebijakan menjadi empat yaitu:

(1) The analysis of failure (model analisis kegagalan). (2) Model rasional (top down) untuk mengidentifikasi faktor-faktor mana yang membuat implementasi sukses. (3) Model pendekatan bottom-up kritikan terhadap model pendekatan top-down dalam kaitannya dengan pentingnya faktor-faktor lain dan interaksi organisasi. (4) Teori-teori hasil sintesis (hybrid theories). ${ }^{11}$

Berikut ini akan diambil beberapa pandangan mengenai implementasi, masing-masing pandangan mewakili tiga dari empat perkembangan model yang dikemukakan Parsons dan

\footnotetext{
${ }^{11}$ Wayne Parsons, Public Policy: An Introduction to the Theory and Practise of Policy Analysis, (Edward Elgar, Cheltenham, UK Lyme. US, 1997), h. 41.
} 
menurut Penulis sesuai dengan tema penelitian model tersebut di antaranya yaitu:

- Model Pendekatan Top-Down

Van Meter dan Van Horn 1975 sebagaimana dikutip Abdul Wahab, memandang implementasi kebijakan sebagai those actions by public or provide individual or group that are directed at the achievement of objectives set forth in prior policy decision. ${ }^{12}$ Yakni tindakan-tindakan yang dilakukan dan atau dimplementasikan oleh individu/pejabat-pejabat atau kelompokkelompok pemerintah atau swasta yang diarahkan pada pencapaian tujuan-tujuan yang telah digariskan dalam keputusan kebijakan.

Keterlibatan aktor/stakeholders dalam implementasi kebijakan MPMBS, jika dilihat dari sudut pandang teori Van Meter dan Van Horn ini, maka keduanya beranjak dari suatu argumen bahwa perbedaan-perbedaan dalam proses implementasi kebijakan akan dipengaruhi oleh sifat kebijakan yang akan dilaksanakan. Selanjutnya keduanya menawarkan suatu pendekatan yang mencoba untuk menghubungkan antara isu kebijakan dengan implementasi dan suatu model konseptual yang mempertalikan kebijakan dengan prestasi kerja (performance) yang berhasil dan dapat dibanggakan.

Kedua tokoh tersebut sepertinya menegaskan pendiriannya bahwa perubahan, kontrol, dan kepatuhan bertindak merupakan konsep-konsep penting dalam prosedur-prosedur implementasi. Dengan memanfaatkan konsep-konsep tersebut, maka permasalahan yang perlu dikaji dalam hubungan ini adalah hambatan-hambatan apakah yang terjadi dalam mengenalkan konsep kebijakan yang ditawarkan.

\footnotetext{
${ }^{12}$ Abdul Wahab S., Analisis Kebijakan dari Formulasi ke Implementasi Kebijaksanaan Negara, (Cet. IV; Jakarta: Bumi Aksara, 2003), h. 31.
} 
Dalam kaitan ini keterlibatan aktor/stakeholders dalam implementasi kebijakan MPMBS perlu dilihat dan dievaluasi. Seberapa jauhkah tingkat efektivitas mekanisme-mekanisme kontrol pada setiap posisi dan kewenangan serta jenjang struktur pelaksana pendidikan yakni menyangkut kekuasaan dari pihak yang paling rendah tingkatannya dalam struktur organisasi lembaga pendidikan sekolah yang bersangkutan.

Dalam implementasi kebijakan MPMBS, keterlibatan aktor/stakeholders penting menjadi pertimbangan dalam pengambilan keputusan. Keterkaitan masing-masing pihak dalam manajemen peningkatan mutu organisasi lembaga pendidikan sekolah menyangkut masalah kepatuhan tidak bisa diabaikan. Atas dasar pandangan tersebut di atas, Van Meter dan Van Horn kemudian berusaha untuk membuat tipologi kebijakan strategis.

Kebijakan strategis menyangkut peningkatan mutu kemudian didasarkan pada jumlah masing-masing perubahan yang akan dihasilkan dan jangkauan atau lingkup kesepakatan terhadap tujuan di antara pihak-pihak yang terlibat dalam proses implementasi. Alasan dikemukakannya pandangan ini ialah bahwa proses implementasi itu akan dipengaruhi oleh dimensidimensi kebijakan semacam itu. Dalam artian bahwa implementasi kebijakan MPMBS, kebanyakan akan berhasil apabila perubahan yang dikehendaki relatif sedikit, sementara kesepakatan terhadap tujuan, terutama dari mereka (pelaksana) yang mengoperasikan program di lapangan relatif tinggi.

Ini berarti keterlibatan aktor/stakeholders dalam implementasi kebijakan MPMBS memang tidak dapat diabaikan. Hal lain yang dikemukakan kedua ahli di atas ialah bahwa jalan yang menghubungkan antara kebijakan dan prestasi kerja dipisahkan oleh sejumlah variabel bebas (independent variable) yang saling berkaitan. Variabel-variabel tersebut adalah ukuran dan tujuan kebijakan, sumber-sumber kebijakan, ciri-ciri atau 
sifat badan/instansi pelaksana, komunikasi antar organisasi terkait, kegiatan-kegiatan pelaksanaan dan sikap para pelaksana.

- Model Pendekatan Bottom-Up

Parsons memandang implementasi sebagai proses atau alur, melihat proses kebijakan dari perspektif perubahan sosial dan politik, di mana kebijakan yang dibuat pemerintah bertujuan untuk mengadakan perbaikan atau perubahan. ${ }^{13}$ Ia mengatakan bahwa ada empat variabel yang perlu diperhatikan dalam proses implementasi kebijakan yaitu:

- Idealized policy adalah suatu pola interaksi yang diidealisasikan perumus kebijakan dengan tujuan untuk memotivasi, mendorong, mempengaruhi, dan merangsang target group untuk kemudian melaksanakannya sehingga dapat berjalan cepat dan tepat sasaran.

- Target group, yaitu bagian dari policy stakeholders yang diharapkan dapat mengadopsi pola-pola interaksi sebagaimana yang diharapkan oleh perumus kebijakan. Karena target group ini banyak mendapat pengaruh dari kebijakan, maka diharapkan dapat menyesuaikan pola-pola prilakunya dengan kebijakan yang dirumuskan.

- Implementing organization, yaitu badan-badan pelaksana atau unit-unit lembaga dan birokrasi pemerintah yang berwenang dan bertanggungjawab dalam implementasi kebijakan

- Environmental faktors, yaitu unsur-unsur di dalam lingkungan yang mempengaruhi implementasi kebijakan (seperti aspek budaya, sosial, ekonomi, dan politik).

Sehubungan dengan implementasi kebijakan MPMBS, model pendekatan bottom-Up, melatarbelakangi keinginan untuk mencermati dan mengkaji secara lebih mendalam mengenai keterlibatan atau partisipasi masyarakat sebagai salah satu

\footnotetext{
${ }^{13}$ Wayne Parsons, Public Policy..., h. 47.
} 
aktor/stakeholders penting dalam implementasi kebijakan MPMBS, serta faktor-faktor apa saja yang menjadi kendala dalam implementasi kebijakan MPMBS, ini masih perlu dikaji dan diteliti secara seksama.

- Model Pendekatan Sintesis (Hybrid theories)

Sabatier $^{14}$ mengkaji implementasi menuju suatu sintesis mengatakan bahwa tahap-tahap kebijakan (policy-stages) tidaklah membantu memahami proses pengambilan kebijakan, karena memilah-milahnya menjadi serangkaian bagian (section) yang sifatnya tidak realistis dan artifisial. Karena itu dari sudut pandang ini, implementasi dan policy-making menjadi kesatuan proses yang sama yang bersifat mutualisme.

Kontribusi awalnya terhadap studi implementasi muncul bersamaan dengan pertimbangan model top-down yang ditulis bersama Mazmanian. Frameworknya kemudian dimodifikasi sesuai dengan riset yang dilakukan Sabatier terhadap evaluasi kasus model bottom-up seperti yang dikembangkan oleh Hjern dan Porter yang mengatakan bahwa implementasi sebagai hubungan inter-organisasi.

Sehubungan dengan hal ini, Sabatier mengemukakan bahwa sintesis dari dua posisi (model top-down dan bottom-up) tersebut dimungkinkan dengan mengambil wawasan dari Hjern dan Porter untuk dipakai pada dinamika implementasi inter-organisasi dalam bentuk network, model top-down memfokuskan perhatiannya pada institusi dan kondisi sosial ekonomi yang menekankan perilaku.

Sintesis ini disempurnakan melalui pemakaian konteks policy subsystem, yaitu semua aktor terlibat secara interaktif satu

\footnotetext{
${ }^{14}$ Lihat selengkapnya Paul A. Sabatier, “Top Down and Bottom-up Approaches to Implementation Research: a Critical Analyis and Suggested Syinthesis" dalam Journal of Public Policy, (1986), h. 197-209.
} 
sama lain dalam proses politik dan kebijakan. Dan dibatasi oleh parameter yang relatif stabil serta kejadian di luar subsystem. Secara lebih jelas bahwa policy subsystem adalah aktor-aktor kebijakan yang berasal dari organisasi baik organisasi publik maupun privat secara aktif mengkaji dan mengkritisi suatu masalah kebijakan tertentu.

Hal penting dari model implementasi kebijakan ini dalam kaitan ini keterlibatan aktor/stakeholders dalam implementasi kebijakan MPMBS adalah kedudukannya sebagai bagian berkesinambungan dari pengambil kebijakan (engonging part of policy making) dalam advocacy coalitions atau pendampingan para aktor/stakeholders kebijakan dengan berbagai elemen yang ada dalam masyarakat.

\section{KENDALA DALAM IMPLEMENTASI KEBIJAKAN MPMBS}

Upaya peningkatan mutu pendidikan tidak pernah berhenti dilakukan oleh pemerintah maupun para aktor/stakeholders. Bahwa dalam implementasi kebijakan MPMBS yang bermutu terlibat berbagai input seperti; bahan ajar (kognitif, afektif, atau psikomotorik), metodologi (bervariasi sesuai kemampuan guru), sarana sekolah, dukungan administrasi dan sarana prasarana dan sumber daya lainnya serta penciptaan suasana yang kondusif.

Implementasi kebijakan MPMBS berfungsi mensinkronkan berbagai input tersebut atau mensinergikan semua komponen dalam interaksi (proses) belajar mengajar baik antara guru, siswa dan sarana pendukung di kelas maupun di luar kelas, baik konteks kurikuler maupun ekstra-kurikuler, baik dalam lingkup subtansi yang akademis maupun yang non-akademis dalam suasana yang mendukung proses pembelajaran.

Mutu dalam konteks hasil pendidikan mengacu pada prestasi yang dicapai oleh sekolah pada setiap kurun waktu 
tertentu. ${ }^{15}$ Mutu atau prestasi yang dicapai atau hasil pendidikan (student achievement) dapat berupa hasil test kemampuan akademis (misalnya ulangan umum, US atau UN). Dapat pula berupa prestasi di bidang lain seperti prestasi di suatu cabang olah raga, seni atau keterampilan tambahan tertentu misalnya: komputer, beragam jenis teknik, jasa.

Bahkan prestasi sekolah dapat berupa kondisi yang tidak dapat dipegang (intangible) seperti suasana disiplin, keakraban, saling menghormati, kebersihan, dsb. Antara proses dan hasil pendidikan yang bermutu saling berhubungan. Akan tetapi agar proses yang baik itu tidak salah arah, maka mutu dalam artian hasil (ouput) harus dirumuskan lebih dahulu oleh sekolah, dan harus jelas target yang akan dicapai untuk setiap tahun atau kurun waktu lainnya.

Meskipun demikian, kendala dalam implementasi kebijakan MPMBS terkadang tidak bisa dihindari. Berbagai input dan proses harus selalu mengacu pada mutu-hasil (output) yang ingin dicapai. Dengan kata lain implementasi kebijakan MPMBS dalam school based quality improvement bukan hanya pada proses, tetapi adalah pada hasil akhir yang dicapai, terutama aspek kemampuan akademik benchmarking (menggunakan titik acuan standar).

Evaluasi terhadap seluruh hasil pendidikan pada tiap sekolah baik yang sudah ada patokannya (benchmarking) maupun yang lain (kegiatan ekstra-kurikuler) dilakukan oleh individu sekolah sebagai evaluasi diri dan dimanfaatkan untuk memperbaiki target mutu dan proses pendidikan tahun berikutnya. Dalam hal ini, implementasi kebijakan MPMBS harus merupakan penjabaran dari target mutu yang ingin dicapai dan skenario bagaimana mencapainya.

\footnotetext{
${ }^{15}$ Widjajati, Anak Jalanan : Studi Kasus tentang Fenomena Pengamen Lampu Merah dan Kebijakan Penanggulangannya di Kota Malang. (Tesis Pascasarjana Universitas Brawijaya, Malang, 2002), h. 44.
} 
Meskipun demikian, kendala-kendala yang menghambat implementasi kebijakan MPMBS tetap saja ada. Kebijakan apapun bentuknya sebenarnya mengandung resiko untuk gagal. John Portz, membagi pengertian kegagalan kebijakan (policy failure) ke dalam dua kategori yaitu non implementation (tidak terimplementasikan) dan unsuccesful implementation (implementasi kebijakan yang tidak berhasil). ${ }^{16}$

Tidak terimplementasikannya kebijakan MPMBS mengandung arti bahwa kebijakan tidak dilaksanakan sesuai dengan rencana, mungkin karena pihak-pihak yang terlibat di dalam pelaksanaannya tidak mau berkerjasama, atau mereka telah bekerja secara tidak efisien, bekerja setengah hati atau karena mereka tidak sepenuhnya menguasai permasalahan, sehingga betapapun gigih usaha mereka, hambatan-hambatan yang ada tidak sanggup mereka tanggulangi.

Implementasi yang tidak berhasil terjadi manakala suatu kebijakan tertentu telah dilaksanakan sesuai dengan rencana, namun mengingat kondisi eksternal ternyata tidak menguntungkan (misalnya tiba-tiba terjadi peristiwa penggantian kekuasaan, bencana alam, dan sebagainya), kebijaksanaan tersebut tidak berhasil dalam mewujudkan dampak/hasil akhir yang dikehendaki. Biasanya kebijakan yang memiliki resiko untuk gagal itu disebabkan oleh beberapa faktor antara lain: pelaksanaannya jelek (bad execution), kebijakannya sendiri jelek (bad policy) atau kebijakan itu memang bernasib jelek (bad luck).

Berkaitan dengan faktor-faktor kendala yang menghambat implementasi kebijakan MPMBS, manajemen menuntut/mengedepankan adanya transparansi, dengan kata lain transparansi merupakan kunci pelaksanaan kebijakan MPMBS. Fakta di lapangan bahwa pelaksana (aktor/stakeholders) yang terlibat belum melaksanakan tugasnya dengan baik, sesuai dengan ketentuan yang telah digariskan dan disepakati bersama.

${ }^{16}$ John Portz, Problem Definitions..., h. 369. 
Dalam hal sosialisasi misalnya, belum dilakukan secara kontinyu dan menyeluruh (bersifat temporer) sehingga konsep dan tujuan kebijakan MPMBS belum dipahami oleh target group atau aktor/stakeholders secara baik, bahkan yang tidak mengerti sama sekali apa itu MPMBS. Di samping itu masih ada ditemukan sekolah yang belum memiliki visi dan misi sekolah dan bahkan kurang mengerti tentang konsep MPMBS.

Fenomena-fenomena ini, sejalan dengan pendapat dari Long sebagaimana dikutip Abdul Wahab, yang mengatakan bahwa dalam banyak kasus, proses implementasi kebijakan akan selalu terbuka peluang adanya "re orientasi" atau transformasi kebijakan. ${ }^{17}$ Praktis tidak ada garis lurus yang membentang serta menghubungkan antara kebijakan dan hasil akhir kebijakan. Pendapat Long ini benar-benar terbukti/terjadi pada implementasi kebijakan MPMBS.

Kendala dalam implementasi kebijakan MPMBS di Sekolah disebabkan oleh beberapa faktor sebagai berikut:

- Kesiapan sumber daya masih rendah, misalnya: (a) Kurangnya buku-buku bacaan penunjang di pustaka sekolah. (b) Tingginya tingkat ketergantungan sekolah terhadap bantuan (seperti: dana, dan lain-lain) dari pemerintah, sehingga mengakibatkan pihak sekolah kurang kreatif/inisiatif, menggali potensi di sekolah bersangkutan. (c) Rendah/kurang profesionalnya Kepala Sekolah dan guru serta tenaga kependidikan dalam mengelola dan melaksanakan pendidikan di sekolah.

- Sosialisasi kebijakan MPMBS intensitasnya masih kurang, temporer, dan dilakukan tidak secara menyeluruh atau total (komprehensif), sehingga tidak dipahaminya konsep dan tujuan MPMBS tersebut secara baik oleh aktor/stakeholders.

- Kemandirian (otonomi) Kepala Sekolah dalam mengelola atau manajemen sekolah masih rendah. Terkesan ragu-ragu, takut

\footnotetext{
${ }^{17}$ Abdul Wahab, S. , Analisis Kebijakan..., h. 33.
} 
salah, dan ketergantungan terhadap petunjuk pelaksanaan dan bantuan pemerintah masih tinggi, sehingga Kepala Sekolah dan jajarannya terkesan statis serta kurang kreatif.

- Adanya kebijakan MPMBS dengan pengimplementasiannya, dipandang oleh sebagian pihak sekolah sebagai suatu beban (meliputi waktu, administrasi dan persyaratan tertentu lainnya) karena semua ini tidak diimbangi oleh kontribusi yang memadai, yang mereka terima sebagai dampak dari program MPMBS ini.

Faktor-faktor yang dikemukakan di atas, perlu menjadi bahan evaluasi untuk menghindari kegagalan dalam implementasi kebijakan MPMBS. Kegagalan implementasi suatu kebijakan cenderung karena faktor ulah manusia, di mana pengambilan keputusan terkadang gagal memperhitungkan kenyataan adanya persoalan manusia (human error) yang sangat komplek dan bervariasi, baik pemerintah sebagai pembuat kebijakan maupun sekolah beserta warganya sebagai pelaku kebijakan dan target group.

Merujuk kepada berbagai kendala atau hambatan yang telah diidentifikasi dari hasil penelitian, dan dikaitkan dengan pandangan atau pendapat ahli mengenai faktor-faktor yang menyebabkan kegagalan implementasi suatu kebijakan, maka Penulis berpendapat bahwa kegagalan implementasi suatu kebijakan, belum tentu sepenuhnya dikarenakan ketidakmampuan pelaksana (aktor/stakeholders), tetapi juga disebabkan karena pembentukan kebijakan.

Disinilah dituntut kepiawaian dari para pelaksana kebijakan (aktor/ stakeholderss) supaya mampu melakukan penyesuaianpenyesuaian atau adaptasi, sehingga proses implementasi dapat berjalan efektif dan tujuan/pokok kebijakan dapat direalisasikan. Dalam hal ini sosialisasi implementasi kebijakan MPMBS harus terus dilakukan untuk memberikan pemahaman dan pencerahan 
kepada semua pihak untuk sama-sama merespon kebijakan tersebut.

Berkenaan juga dengan faktor penyebab kegagalan implementasi kebijakan MPMBS, Wohlstetter dan Mohrmann dalam hasil penelitian mengungkapkan empat macam kegagalan implementasi, yaitu Pertama, sekedar mengadopsi model apa adanya atau tidak ada upaya kreatif. Kedua, Kepala Sekolah bekerja berdasarkan agenda kerja sendiri tanpa memperhatikan aspirasi warga sekolah. Ketiga, kekuasaan pengambilan keputusan terpusat pada satu pihak. Keempat, menganggap MPMBS adalah hal yang biasa dengan tanpa usaha yang serius akan berhasil dengan sendirinya, padahal pada kenyataannya implementasi MPMBS memakan waktu, tenaga, pikiran secara besar-besaran.

Keempat indikator yang telah dipaparkan di atas, mengisyaratkan bahwa guna menghindari kegagalan implementasi kebijakan MPMBS tersebut, maka diperlukan keterlibatan atau partisipasi aktif semua pelaku kebijakan (koalisi aktor/stakeholderss) untuk mengkaji, memahami dan melakukan penyesuaian atau adaptasi (reformulasi) yang dilandasi azas kerjasama, keterkaitan, kebersamaan dan akuntabilitas serta transparan.

Implementasi kebijakan MPMBS perlu didukung oleh semangat demokrasi dan transparansi menuju suatu komitmen/ konsensus agar implementasi kebijakan MPMBS berjalan dengan baik, dan tujuan kebijakan (meningkatkan mutu pendidikan) tercapai. Koalisi aktor/stakeholderss yakni Kepala Sekolah, guru, siswa, orang tua siswa, masyarakat, Komite Sekolah/BP3, pejabat pemerintah terkait, peduli terhadap kegiatan pendidikan di sekolah.

\section{PENUTUP}

Dari ulasan yang dikemukakan di atas, Penulis menarik beberapa kesimpulan sebagai berikut: 
- Dilihat dari jumlah personil sekolah, rasio jumlah guru dan murid, kualifikasi pendidikan dan kepangkatan (ruang/golongan) yang dimiliki, maka Kepala Sekolah dan guru sebagai aktor/stakeholders utama kebijakan MPMBS, dapat dikatakan telah siap dalam mengemban tugas untuk mengimplementasikan kebijakan MPMBS ini. Sebab, mereka memenuhi syarat/standar kelayakan untuk mengajar (melaksanakan tugas dalam proses belajar mengajar) di sekolah. Akan tetapi dilihat secara kualitas, meliputi sikap dan kemampuan profesionalisme, kepemimpinan transformasional, kreatifitas yang dimiliki Kepala Sekolah dan guru, maka dapat dikatakan bahwa Kepala Sekolah dan guru, belum siap untuk mengimplementasikan kebijakan MPMBS tersebut.

- Dilihat dari aspek kelembagaan, yakni organisasi sekolah seperti: Kelompok Kerja Guru (KKG), Kelompok Kerja MPMBS, dan Komite Sekolah/BP3 dan organisasi masyarakat pemerhati pendidikan lainnya cukup tersedia. Yang menjadi persoalan adalah pemberdayaan organisasi-organisasi tersebut masih kurang. Hal ini disebabkan kurang informasi yang didapatkan atau diberikan kepada organisasi tersebut sehingga konsep dan tujuan kebijakan MPMBS tidak dipahami secara baik oleh semua aktor/stakeholders yang terlibat dalam organisasi sekolah. Dengan kata lain masih kurangnya komunikasi dan koordinasi diantara pelaku kebijakan, dikarenakan intensitas sosialisasi kebijakan masih bersifat temporer, dan tidak menyeluruh serta tidak kontinyu.

- Untuk mengelola dan menerapkan kebijakan MPMBS maka kepada Kepala Sekolah, sebagai aktor/stakeholders utama kebijakan ini membentuk jaringan kerja dengan organisasi masyarakat lainnya yang peduli pendidikan. Begitu pula keterlibatan atau partisipasi masyarakat dalam implementasi kebijakan MPMBS masih bersifat eksentif yakni partisipasi yang masih berorientasi pada pembiayaan dan pembangunan 
fisik. Secara umum inisiatif masih datang dari pihak sekolah. Akan tetapi walaupun bersifat ekstensif, tapi kontribusinya cukup signifikan.

\section{DAFTAR PUSTAKA}

Abdul Wahab S., Analisis Kebijakan dari Formulasi ke Implementasi Kebijakan Negara, Cet.IV; Jakarta: Bumi Aksara, 2003.

Depdiknas, Manajemen Peningkatan Mutu Berbasis Sekolah, Jakarta: Direktorat Pendidikan Menengah Umum, 2000.

Hasri, Salfen, Kepemimpinan Kepala Sekolah dari Kerangka Desentralisasi dan Otonomi Sekolah. Edisi Khusus-HUT-FEUM. Oktober, 2002.

Nurkolis, “Manajemen Berbasis Sekolah: Strategi Sukses Implementasi MBS" dalam Article Pendidikan Network (English), Juni, 2001.

Parakasi, Umaedi, Manajemen Peningkatan Mutu Berbasis Sekolah, Cet. VIII; Malang: UMM Press, 2005.

Parsons, Wayne, Public Policy: An Introduction to the Theory and Practise of Policy Analysis. Edward Elgar, Cheltenham, UK Lyme. US, 1997.

Portz, John, "Problem Definitions and Policy Agendas: Shaping the Educational Agenda in Boston" dalam Journal Policy Studies, Vol. 24, 2009.

Rumtini dan Jiyono, "Manajemen Berbasis Sekolah: Konsep dan Kemungkinan Strategi Pelaksanaannya di Indonesia" dalam Jurnal Pendidikan dan Kebudayaan, Juni Tahun Ke 5 No. 017. 2008.

Salladien, Alternatif Model Pendidikan Berorientasi Dunia Kerja, Edisi Khusus-HUT-FE-UM. Oktober, 2002. 
Sabatier, Paul A., "Top Down and Bottom-up Approaches to Implementation Research: a Critical Analyis and Suggested Syinthesis" dalam Journal of Public Policy, 1986.

Widjajati, H. Anak Jalanan: Studi Kasus tentang Fenomena Pengamen Lampu Merah dan Kebijakan Penanggulangannya di Kota Malang. Tesis. Pascasarjana Universitas Brawijaya, Malang, 2002. 
Vol. 10, No. 1, Juni 2013: 151-175 